\title{
Lectotypification of Stipa czerepanovii (Poaceae)
}

Marcin Nobis \& Polina Gudkova

Lectotypification of Stipa czerepanovii (Poaceae).- Čas. Slez. Muz. Opava (A), 60: 199-200, 2011.

\begin{abstract}
The paper presents lectotypification of Stipa czerepanovii Kotuch. described from the Zaisan basin (eastern Kazakstan). The material designated as the type of Stipa czerepanovii is deposited in the herbarium of the Komarov Institute of Botany, Russian Academy of Sciences (St.Petersburg) and composed of three sheets. However, specimens on one of the sheets, represent other species of Stipa, and according the Viena code the lectotype should be designated.
\end{abstract}

Keywords : lectotype, Stipa, Kazakhstan

\section{Introduction}

The genus Stipa L. contains about 50 species in Kazakhstan (Roshevitz 1934, Pavlov 1956, Pazij 1968, Tzvelev 1976, Abdulina 1999, Kotukhov 2002, Nobis 2010, 2011). 18 of them have been described in the last 25 years by Kotukhov (1987, 1989, 1991, 1994, 1998a, 1998b). A considerable number of more widespread and relatively local species (with very narrow ranges) as well as taxa with hybrid origin have been described by this researcher, from south-western Altai Mts (eastern Kazakhstan).

In this paper, lectotypification of Stipa czerepanovii Kotuch. name described by Yu. Kotukhov, base on material from Zaisan basin (eastern Kazakhstan) is designated. In the type collection of $S$. czerepanovii deposited in the herbarium of the Komarov Institute of Botany, Russian Academy of Sciences (St.-Petersburg) (LE), there are three herbarium sheets with specimens determined by Kotukhov as types of $S$. czerepanovii (without distinguishing a holotype). The specimens on two of them has the hairs of the seta up to $1.5 \mathrm{~mm}$ long and corresponding to the original description of Stipa czerepanovii. Whereas the third sheet has two specimens which have much longer hairs at the seta and represent Stipa orientalis Trin. From this reason, according the Viena code (Mc-Nill at al. 2006), the lectotype should be designated. However, necessity of this typification is a result of mistakes and mixed of herbary labels during preparation of sheets, rather then mistakes of the species author.

Stipa czerepanovii belongs to the section Barbatae A. Junge, and to date is know only from the locus classicus (Kotukhov 2002).

\section{Lectotype description}

Stipa czerepanovii KoтUch. (1998b) [Novye vidy roda Stipa L. (Poaceae) iz vostochnogo Kazakhstana (New species of the genus Stipa L. (Poaceae) from western Kazakhstan). - Turczaninowia 1: 13]

LECTOTYPE (designated here): 'Zaisanskaya kotlovina, obnazheniya tretichnykh glin Akseir (vostochnaya okraina), yugo-zapadnyi galechno-glinistyi sklon gryady, 17 Jun 1993, Yu. Kotykhov (LE!). The lectotype is the specimen on the right side of the herbarium sheet, two others are isolectotypes. Other isolectotypes: the second herbarium sheet with two specimens of $S$. czerepanovii (labeled accordingly by M. Nobis in 2011) (LE!).

\section{References}

Abdulina S. A. (1999): Checklist of vascular plants of Kazakhstan. Ministry of Sci. Acad. Sci. of the Kazakhstan Inst. of Bot. and Phytointroduction.

Kotukhov Yu. (1987): Novyi vid roda Stipa (Poaceae) iz yuzhnogo Altaya (A new species of the genus Stipa (Poaceae) from southern Altai). - Bot. Zhurn., 72: 1254-1255.

- (1989): Novye taksony rodov Stipa (Poaceae) i Oxytropis (Fabaceae) iz vostochnogo Kazakhstana (Some new taxa of the genera Stipa (Poaceae) and Oxytropis (Fabaceae) from the western Kazakhstan). - Bot. Zhurn., 74: 414-416.

- (1991): Novye vidy roda Stipa (Poaceae) iz yuzhnogo Altaya (New species of the genus Stipa (Poaceae) from southern Altai). - Bot. Zhurn., 76: 872-874.

- (1994): Novye vidy roda Stipa (Poaceae) iz yuzhnogo Altaya, Saura i Tarbagataya (New species of the genus Stipa (Poaceae) from south Altai, Saur and Tarbagatai). - Bot. Zhurn. 79: 101-106. 
- (1998a): Novye vidy zlakov (Poaceae) iz yuzhnogo Altaya, Saura i Tarbagataya (New species of grasses (Poaceae) from south Altai, Saur and Tarbagatai). - Turczaninowia, 1: 7-21.

- (1998b): Novye vidy roda Stipa L. (Poaceae) iz vostochnogo Kazakhstana (New species of the genus Stipa L. (Poaceae) from western Kazakhstan). - Turczaninowia, 1: 9-16.

- (2002): Konspekt kovylei (Stipa L.) i kovylechkov (Ptilagrostis Griseb.) vostochnogo Kazakhstana (Kazakhstanskii Altai, Zaisanskaya kotlovina i Prialtaiskie khrebty). - Bot. Issl. Sib. Kazakhst., 8: 3-16.

McNeill J. et al. (eds.) (2006): International Code of Botanical Nomenclature (Vienna Code) adopted by the Seventeenth International Botanical Congress Vienna, Austria, July 2005. A.R.G. Gantner Verlag, Ruggell. [Regnum Veg. 146].

Nobis M. (2010): Stipa adamii sp. nov. (Poaceae) from the western Tian-Shan, and some remarks on the taxa of the section Smirnovia occurring in Kazakhstan. - Nordic J. Bot., 28: 728-733.

- (2011): Stipa kotuchovii, nom. nov. (Poaceae). - Ann. Bot. Fennici, 48(6): 494.

Pavlov N. V. (1956): Flora Kazakhstana. 1. Izdat. Akad. Nauk Kazakhskoi SSR.

Pazij V. K. (1968): Stipa. In: Kovalevskaya, S. S. (ed.) Opredelitel' rastienii sredniei Azii (Conspectus florae Asiae Mediae). Vol. 1. Ed. Acad. Sci. USSR, pp. 64-82.

Roshevitz R. Yu. (1934): Stipa L. In: Komarov V. L. (ed.), Flora SSSR. Vol. 2. Ed. Acad. Sci. URSS, pp. 79-112, 740-741.

Tzvelev N. N. (1976): Zlaki SSSR (Grasses of the Soviet Union). - Nauka.

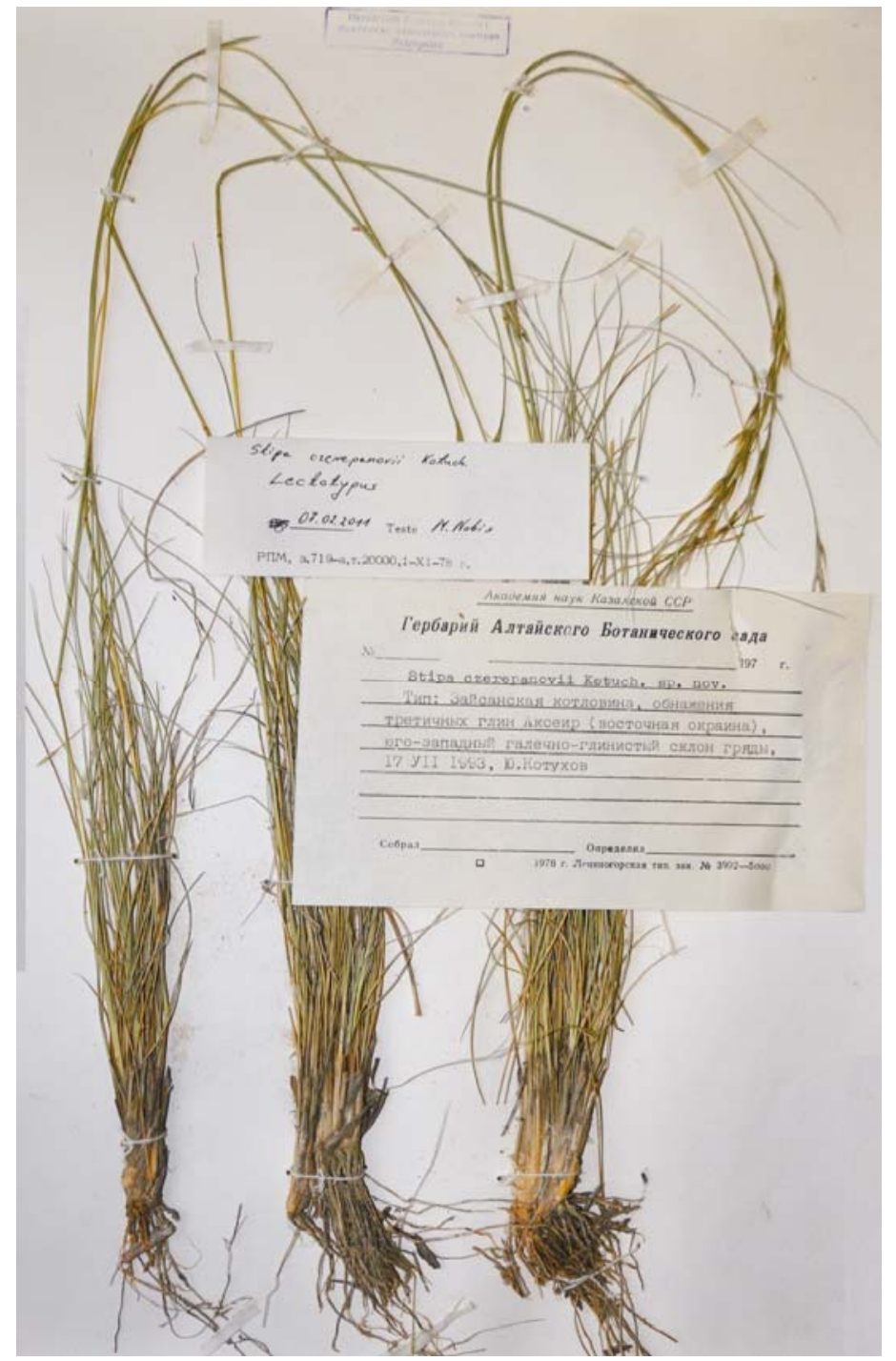

Fig. 1: Lectotype of the Stipa czerepanovii Kotuch. in the herbaruim of LE (St.-Petersburg)

Authors' addresses: Marcin Nobis, Dept. of Plant Taxonomy, Phytogeography \& Herbarium, Inst. of Botany, Jagiellonian University, Kopernika 27, PL-31-501 Kraków, Poland; e-mail: m.nobis@uj.edu.pl

Polina Gudkova, Dept. of Botany, Inst. of Biology, Tomsk State University, 36 Lenin Prospekt, Tomsk, 634050, Russia; e-mail: polina-shavrova@yandex.ru 